\title{
Correction to: Charles Goodhart and Manon Pradhan: The great demographic reversal: ageing societies, waning inequality, and an inflation revival
}

\section{Palgrave Macmillan, 2020}

\section{Robert Eisenbeis ${ }^{1}$}

Published online: 20 April 2021

(c) National Association for Business Economics 2021

\section{Correction to: Business Economics} https://doi.org/10.1057/s11369-020-00203-2

The article "Charles Goodhart and Manon Pradhan: The great demographic reversal: ageing societies, waning inequality, and an inflation revival", written by Robert Eisenbeis, was originally published online on the publisher's internet portal on 26 January 2021 with Open Access under a Creative Commons Attribution (CC BY) license 4.0.

With the author's/authors' decision to cancel Open Access the copyright of the article changed on 07 April 2021 to $\odot$ National Association for Business Economics 2021.

Publisher's Note Springer Nature remains neutral with regard to jurisdictional claims in published maps and institutional affiliations. 